\title{
Suspended sediment dynamics at different time scales in the Loushui River, south-central China
}

\author{
Liying Sun, Ming Yan, Qiangguo Cai, Haiyan Fang * \\ Key Laboratory of Water Cycle and Related Land Surface Processes, Institute of Geographic Sciences and Natural Resources Research, Chinese Academy of Sciences, Beijing 100101, China
}

\section{A R T I C L E I N F O}

\section{Article history:}

Received 14 August 2014

Received in revised form 23 January 2015

Accepted 17 February 2015

Available online 12 March 2015

\section{Keywords:}

Temporal scale

Suspended sediment dynamic

Hysteresis loop

Flood event

Sediment availability

\begin{abstract}
A B S T R A C T
Suspended sediment dynamics were investigated in the Loushui River basin, a secondary tributary of the Yangtze River in southern China. The variations of suspended sediment transport were analyzed at different time scales (among different years, monthly and seasonal, and within-flood event) based on 25-year hydrological data from the outlet hydrometric station, and explained by the contribution of flood events, precipitation and human activities. Four stages were classified by the non-parametric statistical method of Pettitt change-point test and Cumulative anomaly test. At the annual scale, the relationship between suspended sediment concentration (SSC) and water discharge $(Q)$ varied at four stages. The suspended sediment load (SSL) showed parabolic relationship with annual precipitation and significantly influenced by floods (contribution averaged at $78 \%$ before 1985; at 55\% after 2007). SSL drastically decreased after 2007, mainly induced by the construction of the Jiangya reservoir. Sediment 'store-release' phenomenon was used to explain the seasonal variations of suspended sediment load. Monthly SSC-Q hysteresis loops indicated that the sediment storage seasons swung between winter/spring and late autumn at different stages. At the within-flood scale, three types of SSC-Q hysteresis loops were observed for the maximum flood events, including clockwise pattern (44\%), counter-clockwise pattern (24\%) and figure-eight pattern (32\%). The variations of SSC-Q hysteresis patterns at four stages implicated the changing suspended sediment source materials with time. During the years 1966-1978, the suspended sediment mainly came from channels for the maximum flood events, while, materials from the upper reaches or slopes dominated the later period 1979-1985 and 2007-2011.
\end{abstract}

(c) 2015 Elsevier B.V. All rights reserved.

\section{Introduction}

More attention has been paid to suspended sediment dynamics in recent decades, due to its significance to many issues, such as the transport of sediment-bound pollutants, siltation, landscape denudation, and related ecological impacts of sediment management (Rovira and Batalla, 2006; Oeurng et al., 2010; Andermann et al., 2012). The quantification of sediment transport is hindered by the temporal variability of water flow and suspended sediment concentration (Rodríguez-Blanco et al., 2010a). Suspended sediment concentration is easily changed with time, due to many factors, such as discharge conditions, availability of sediment, climate, tectonics, lithology, as well as different kinds of human activities (Rodríguez-Blanco et al., 2010b). The impacts of rainfall on water yield and suspended sediment were intensively investigated in both small catchments and large rivers (Oeurng et al., 2010; López-Tarazón et al., 2010; Fang et al., 2011; Chen et al., 2014). The results are inconsistent for catchments in different environments. Some investigations observed close correlations between rainfall and runoff as well as between runoff and suspended sediment load (Oeurng

\footnotetext{
* Corresponding author.

E-mail address: fanghy@igsnrr.ac.cn (H. Fang).
}

et al., 2010; Fang et al., 2011; Chen et al., 2014). Others found a more complicated relationship. For example, Rodríguez-Blanco et al. (2010b) indicated that water discharge $(Q)$ showed a better correlation with base flow than with rainfall, and the suspended sediment load (SSL) showed a stronger correlation with $Q$ than with rainfall. In addition, the runoff and sediment load variations may be attributed to human activities, like reservoir dams (Walling and Fang, 2003; Batalla et al., 2004), soil and water conservations (Miao et al., 2011; Wang et al., 2012a), water diversion and reforestation (Brown et al., 2005; Walling, 2006).

The hysteresis loop between suspended sediment concentration and water discharge (SSC-Q hysteresis loop) has been widely examined, because the SSC-Q hysteresis patterns are results from complicated factors and processes, such as event discharge, catchment erosion and human activities, and thus provide significant information on suspended sediment source (Nistor and Church, 2005; Gao and Pasternack, 2007). The shape of the hysteresis loop presents different kinds of forms, including linear, clockwise, counter-clockwise, single line plus a loop and figure-eight, depending on the mechanisms underlying sediment transport processes (Williams, 1989; Nistor and Church, 2005; Fan et al., 2012). For rivers or watersheds, where sediment transport is mainly induced by floods, clockwise hysteresis is quite normal, 
indicating sediment within runoff event or rapid delivery of sediment from channel banks (Picouet et al., 2001; Richards and Moore, 2003; Nistor and Church, 2005; Smith and Dragovich, 2009). However, counter-clockwise and figure-eight hysteresis may suggest the delay of sediment entrainment within runoff event (Duvert et al., 2010; Nistor and Church, 2005). Although many studies have been conducted on SSC-Q hysteresis loops, there is still partial understanding of the internal dynamics of suspended sediment variation (Rovira and Batalla, 2006; Gao and Pasternack, 2007).

Zhangjiajie region, at northwest Hunan Province of China, is famous for the large number of sandstone peaks. Due to the significant scientific value, outstanding natural beauty and esthetic importance, the Wulingyuan Scenic and Historic Interest Area in the Zhangjiajie region was inscribed on the World Heritage List in 1992 and a global geopark was established in the sandstone area of Zhangjiajie in 2004 (Yang et al., 2012). Despite growing investigations on the geomorphic characteristics, formation mechanisms and evolutionary processes at Zhangjiajie, there is less knowledge of well understanding this area, such as sediment dynamics in rivers of this area, the geomorphic effects of the sediment transport, sediment sources and erosion rates (Yang et al., 2011a). Loushui River is selected as the study area in this work, which is one of the secondary tributaries of the Yangtze River passing through Zhangjiajie region. Specific objectives of this work were (i) to analyze the dynamics of suspended sediment transport at different temporal scales (among different years, monthly and seasonal, withinflood event) and (ii) to explain the suspended sediment dynamics in terms of flood events, precipitation and human activities.

\section{Materials and methods}

\subsection{Study area}

Loushui River $\left(109^{\circ} 45^{\prime}-111^{\circ} 5^{\prime} \mathrm{E}\right.$ and $\left.29^{\circ} 16^{\prime}-30^{\circ} 39^{\prime} \mathrm{N}\right)$ is the secondary tributary of the Yangtze River, passing through Zhangjiajie region in the humid subtropical south-central China (Fig. 1). Loushui River covers an area of $5417 \mathrm{~km}^{2}$, with a length of $250 \mathrm{~km}$ and total drop of $1670 \mathrm{~m}$. The max and min elevations of the river basin are
$2211 \mathrm{~m}$ and $113 \mathrm{~m}$, respectively. The river basin is dominated by mountainous humid subtropical climate with a mean annual temperature of about $16.3-16.8{ }^{\circ} \mathrm{C}$. The annual precipitation varied from 1138 to $2034 \mathrm{~mm}$ during the period 1959-1985 and 2007-2011, with a mean annual precipitation of about $1562 \mathrm{~mm}$. Spatially, the precipitation $(P)$ decreased from northwest to southeast with the similar trend of varying elevation. About 68\% of annual precipitation falls between April and September. High-intensity and short-duration rainstorms mainly occurred from May to July, accounting for about $30 \%$ of the total annual precipitation.

Loushui River basin is mainly located in Wuling mountain area with the average gradient of $24^{\circ}$. Soils are developed in the weathering crust of the sedimentary rocks, with mainly red soil, yellow soil, purple soil, calcareous soil, fluvo aquic soil and paddy soil. The vegetation types are mainly mountain Pine, Fir, Castanopsis, Phoebe bournei, Tung tree and Bamboo. The forest areas were reduced due to the deforestation and cultivation in 1950s-1970s. After that, small-scale reforestation was carried out without efficient management. According to the results by the forest census in 1984, the vegetation coverage in middle river could reach $80 \%$. In the lower reaches, the landscape is mainly characterized by sandstone landform with the average vegetation coverage at approximately $30 \%$. The land use types are mainly forest and shrub, accounting for more than $60 \%$ of the river basin. By 2000 , the cultivated land was dominated by dry land ( $4 \%$ of the area) and paddy field ( $3 \%$ of the area). Soil erosion was serious before 1985 , mainly due to the deforestation. Soil conservation efforts have been conducted in this area since 1983, dominated by the establishment of terraces in slope farm land. Then large scale reforestation was conducted since 1990, such as the Shelter Forest Ecology Project in the Yangtze River basin started in 1990 and the National Program to Reconvert Farmland to Forests started in 2000. Small-sized reservoirs (water storage capacity smaller than $10^{7} \mathrm{~m}^{3}$ ) are constructed in 1950s-1970s. Medium- and largesized reservoirs were mainly constructed after 1990 . The largest reservoir (water storage capacity at $174 \times 10^{7} \mathrm{~m}^{3}$ ), named Jiangya reservoir, was constructed during 1994-1999 for the purpose of flood control. The information on human activities comes from Cili County annals (1978-2002).

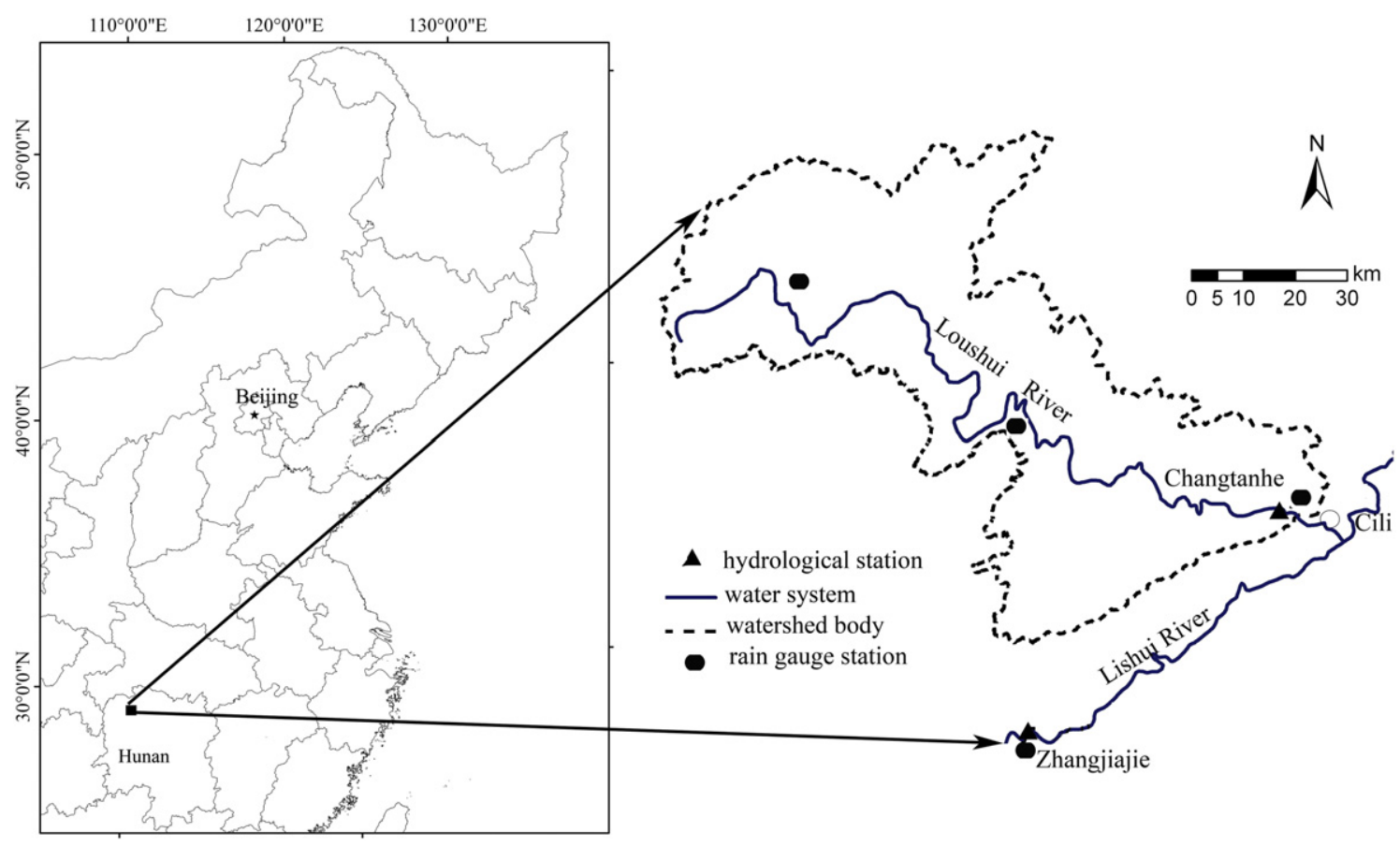

Fig. 1. Location of the Loushui River Basin. 


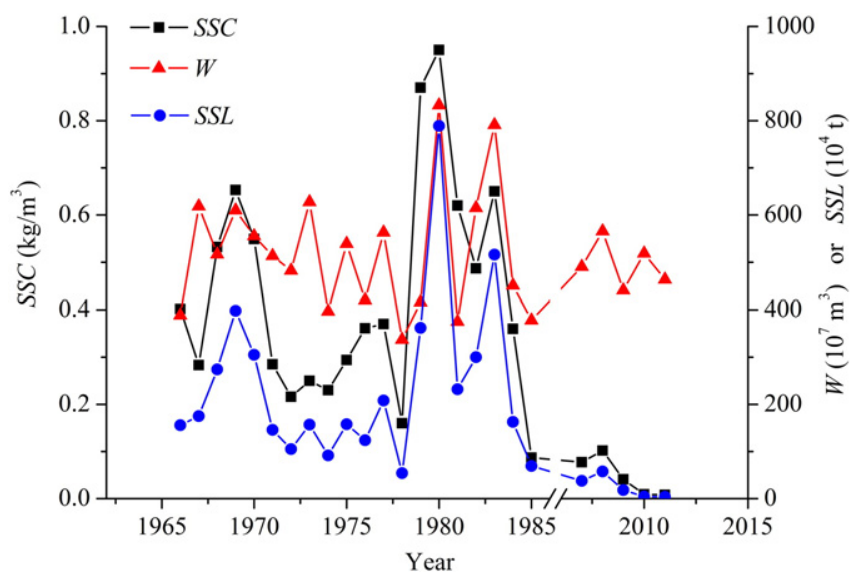

Fig. 2. Annual values of suspended sediment load (SSL), water yield (W) and suspended sediment concentration (SSC) at Changtanhe hydrometric station during the studied period.

\subsection{Data sources}

A dense network of hydrometric stations was established by the Changjiang Water Resources Commission for the purposes of engineering design and scientific research since the 1950s. In these stations, water discharge and suspended sediment concentration were measured regularly. And intensive samplings were conducted to monitor flood events, which usually occurred in a short period of time. The Changtanhe hydrometric station $\left(111^{\circ} 01^{\prime} \mathrm{E}, 29^{\circ} 28^{\prime} \mathrm{N}\right)$ is located at $9 \mathrm{~km}$ from the intersection of the Loushui River into the Lishui River. The control area of the Changtanhe hydrometric station is about $4913 \mathrm{~km}^{2}$, approximately $90 \%$ of the whole Loushui River basin. Thus, Changtanhe hydrometric station is selected for the present research. All data, water discharge $(Q)$, water yield $(W), S S C$, SSL and $P$ were obtained from the Chinese Hydrological Yearbooks issued by the Changjiang Water Resources Commission (1966-1985 and 2007-2011). Data during the period 1986-2007 were missing. Flow velocity was measured by current meter on the ship. According to the circumstances, the $Q$ data were determined by single-curve method, temporary curve or continuous measured flow process line based on the Chinese national standard criterion ("River flow test specification"). Suspended sediment samples were collected by the collapsible bag sampler (ANX-LS) using vertical mixing method based on Chinese national standard criterion ("River suspended sediment test specification"). SSC were determined by drying method. P data (1954-2011) were collected from three precipitation stations, Hefeng, Guandiping and Changtanhe, located along the Loushui River basin. The annual areal precipitation data (calculated from the arithmetic mean annual precipitations of different stations) were used. Land use data of the Loushui River basin were extracted from LANDSAT/TM remote sensing images for the years 1986 to 2000 .

\subsection{Data analysis}

\subsubsection{Suspended sediment load series classification}

Two methods, Pettitt's test (Pettitt, 1979) and Cumulative anomaly (Wang et al., 2012a,b), were used to test the changing tendency of the SSL series. The Pettitt change point test is a non-parametric test based on a version of the Mann-Whitney statistic $U_{t, N}$, which is given by

$U_{t, N}=U_{t-1, N}+\sum_{j=1}^{N} \operatorname{sgn}\left(x_{t}-x_{j}\right), t=2,3, \ldots, N$ where, $x_{t}$ and $x_{j}$ are the sequential data values, $N$ is the data set record length, and

$$
\operatorname{Sgn}\left(x_{t}-x_{j}\right)=\left\{\begin{array}{cc}
+1 & \left(x_{t}-x_{j}>0\right) \\
0 \text { if } & \left(x_{t}-x_{j}=0\right) \\
-1 & \left(x_{t}-x_{j}<0\right)
\end{array}\right.
$$

The statistic $K_{t}$ and the associated significance testing are specified as

$K_{t, N}=\operatorname{Max}\left|U_{t, N}\right|, \quad(1 \leq t \leq N)$

and

$p \cong 2 \exp \left[-6\left(K_{t, N}\right)^{2} /\left(N^{3}+N^{2}\right)\right]$.

If $p<0.05$, a significant change point exists.

Cumulative anomaly method could also be used to identify the changing tendency of discrete sequential variables, such as sequential runoff and suspended sediment concentration (Ran et al., 2010; Wang et al., 2012a,b). It is a statistical method to visually identify the change tendency of discrete data and is extensively used in meteorology (Ran et al., 2010). For a discrete series $x_{i}$, the Cumulative anomaly $\left(X_{t}\right)$ for data point $x_{t}$ can be expressed as

$X_{t}=\sum_{i=1}^{t}\left(x_{i}-x_{m}\right), t=1,2, \ldots, n, \quad x_{m}=1 / n \sum_{i=1}^{n} x_{i}$

where $x_{m}$ is the mean value of the series $x_{i}$, and $n$ is the number of discrete data points. The Cumulative anomaly method could be used to analyze the inflection extent of a discrete data series.

\subsubsection{Flood event determination}

In this study, flood event was identified visually with rising and falling limbs in the hydrograph with the peak flow higher than $600 \mathrm{~m}^{3} / \mathrm{s}$. The base flow was not separated from the storm flow. Totally, 140 flood events were determined during the studied period. The maximum flood event was determined by both the maximum peak suspended sediment concentration $\left(M S S C_{p}\right)$ and the maximum peak water discharge $\left(M Q_{p}\right)$ of the floods, in case these two variables did not occur in the same flood event.

\subsubsection{Categorization of SSC-Q hysteresis patterns}

At monthly and seasonal scales, the averaged $Q$ and SSC values were used for analyzing SSC-Q hysteresis patterns. Within-flood event, the analysis of SSC-Q hysteresis patterns involved hydrograps, sediment graphs and SSC-Q hysteresis loops for the maximum flood events. The categorization of SSC-Q hysteresis patterns at different time scales was determined mainly according to the patterns observed and described by previous literature (Williams, 1989; Jansson, 2002).

\subsubsection{Correlation analysis}

The correlations of $W, Q, S S C, S S L$ and $P$ were analyzed using the curve estimate functions of the program SPSS 13.0 with the analysis of variance (ANOVA) at significance level of $p<0.05$. The definitions of different variables are as follows:

W water yield;

Q water discharge;

SSC suspended sediment concentration;

SSL Suspended sediment load;

$P \quad$ annual precipitation. 


\section{Results}

\subsection{Annual variations}

\subsubsection{SSL variations among different years}

The annual SSL ranged from $54 \times 10^{4}$ t to $789 \times 10^{4}$ t before 1985 and dramatically decreased after $2007\left(4 \times 10^{4} \mathrm{t}-58 \times 10^{4} \mathrm{t}\right)$, with an average value of $239 \times 10^{4} \mathrm{t}$ before 1985 and $24 \times 10^{4} \mathrm{t}$ after 2007 (Fig. 2). The average SSC varied from 0.09 to $0.95 \mathrm{~kg} / \mathrm{m}^{3}$ (averaged at $0.43 \mathrm{~kg} / \mathrm{m}^{3}$ ) before 1985 and from 0.01 to $0.10 \mathrm{~kg} / \mathrm{m}^{3}$ (averaged at $0.05 \mathrm{~kg} / \mathrm{m}^{3}$ ) after 2007. In contrast, the annual $W$ did not change much before 1985 and after 2007, with an average of $521 \times 10^{7} \mathrm{~m}^{3}$ and $496 \times 10^{7} \mathrm{~m}^{3}$, respectively.

Pettitt test and Cumulative anomaly test were used to determine the changing points of the SSL series. The Pettitt test result (Fig. 3a) showed one significant changing point at $1984(p<0.05)$, and two other inflection points (1970, $p=0.68 ; 1978, p=1.73$ ). The Cumulative anomaly test results (Fig. 3b) for sequential SSL (1966-1985) were characterized by a four-stage process with 1970, 1978 and 1983 as turning points. According to the Pettitt test results and the Cumulative anomaly test results, six stages are classified as 1966-1970, 1971-1978, 1979-1983, 1983-1984, 1984-1985 and 2007-2011. Because there is only one year in the period 1983-1984 and 1984-1985, three periods (1979-1983, 1983-1984, 1984-1985) are merged into one period (1979-1985). Ultimately, four stages were classified as 1966-1970, 1971-1978, 1979-1985 and 2007-2011. In these four stages, the mean $W$ values were approximately $540 \times 10^{7}, 450 \times 10^{7}, 520 \times 10^{7}$ and $500 \times 10^{7} \mathrm{~m}^{3}$, respectively. And the mean SSL values were about $261 \times 10^{4}, 127 \times 10^{4}, 256 \times 10^{4}$ and $24 \times 10^{4}$ t, respectively.

\subsubsection{Contribution of flood events to annual SSL}

There were total 130 flood events during the period 1966-1985 and 10 flood events during the years 2007-2011. The peak suspended sediment concentration $\left(S S C_{p}\right.$ ) of the flood events ranged from 0.68 to $18.4 \mathrm{~kg} / \mathrm{m}^{3}$ in period $1966-1985$, and from 0.07 to $3.09 \mathrm{~kg} / \mathrm{m}^{3}$ in the years 2007-2011. The peak water discharge $\left(Q_{p}\right)$ ranged from 629 to $7050 \mathrm{~m}^{3} / \mathrm{s}$ during the years $1966-1985$ and from 969 to $3560 \mathrm{~m}^{3} / \mathrm{s}$ during the years 2007-2011. The duration of the flood events varied from 10 to $170 \mathrm{~h}$, with an average value of $60 \mathrm{~h}$. All flood events occurred between April and September, being consistent with the dominant precipitation season.

The contributions of flood events to the annual $W$ were $16 \%-48 \%$ (averaged at 31\%) during the years 1966-1985 and 1.5\%-5.0\% (averaged at 3\%) in years 2007-2011 (Fig. 4). The contribution of flood events to the annual SSL was much higher, ranged from $36 \%$ to 91\% (averaged at 78\%) during the years 1966-1985 and decreased in years 2007-2011 (averaged at 55\%). This implied that flood events have more significant effects on SSL than influences on $W$ in the Loushui River. The contribution of the maximum flood event to the annual SSL

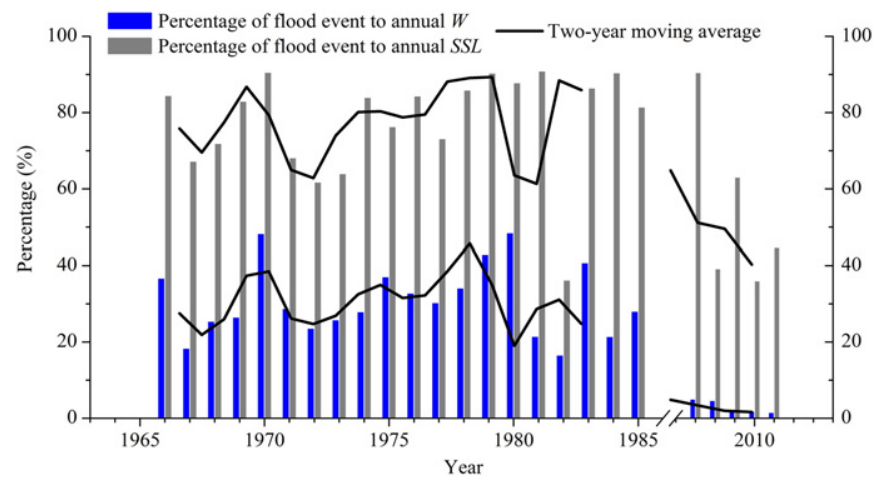

Fig. 4. Contributions of flood events to annual suspended sediment load and water yield.

ranged from $6 \%$ to $73 \%$ (averaged at $32 \%$ ) in years 1966-1985 and from $26 \%$ to $59 \%$ (averaged at $41 \%$ ) in the period 2007-2011 (Fig. 5). Being inconsistent with the decrease in the contribution of flood events to the annual SSL, the mean contribution of the maximum flood events was increased after 2007.

\subsubsection{SSC $-Q$ relations at four stages}

As shown in Table 1, the estimate SSC-Q relations were different at four stages (1966-1970, 1971-1978, 1979-1985 and 2007-2011). No significant relations were estimated during years 1966-1970 and 2007-2011. The normal power functions were fitted for SSC-Q relations during the period $1971-1978\left(S S C=0.015 Q^{0.553^{*}}, R^{2}=0.568\right)$ and $1979-1985\left(S S C=0.018 Q^{0.687^{* *}}, R^{2}=0.823\right)$, which suggested that the SSC normally increased with $Q$ (Ferguson, 1986) in these two stages.

\subsection{Monthly and seasonal variations of SSL}

The monthly SSL ranged from $0.01 \times 10^{4}$ to $59.77 \times 10^{4} \mathrm{t}$ and the monthly $W$ ranged from $11.7 \times 10^{7}$ to $98.1 \times 10^{7} \mathrm{~m}^{3}$. As shown in Fig. 6, monthly variations of suspended sediment contribution (Sc) and water yield contribution (Wc) to the annual value could reach $33 \%$ and $19 \%$, respectively, with the highest contributions occurring in July.

The seasonal variations of $S c$ and $W c$ have similar trend (Fig. 6), following the order as summer (June to August) > spring (March to May) > autumn (September to November) > winter (December to February). Approximately $71 \%$ of the total annual suspended sediment was transported during summer with approximately $46 \%$ of the annual water yield. In other seasons, a lower proportion of suspended sediment was transported by higher proportion of $W$. For example, approximately $0.08 \%$ of the suspended sediment was transported with $7.63 \%$ of water yield during winter.
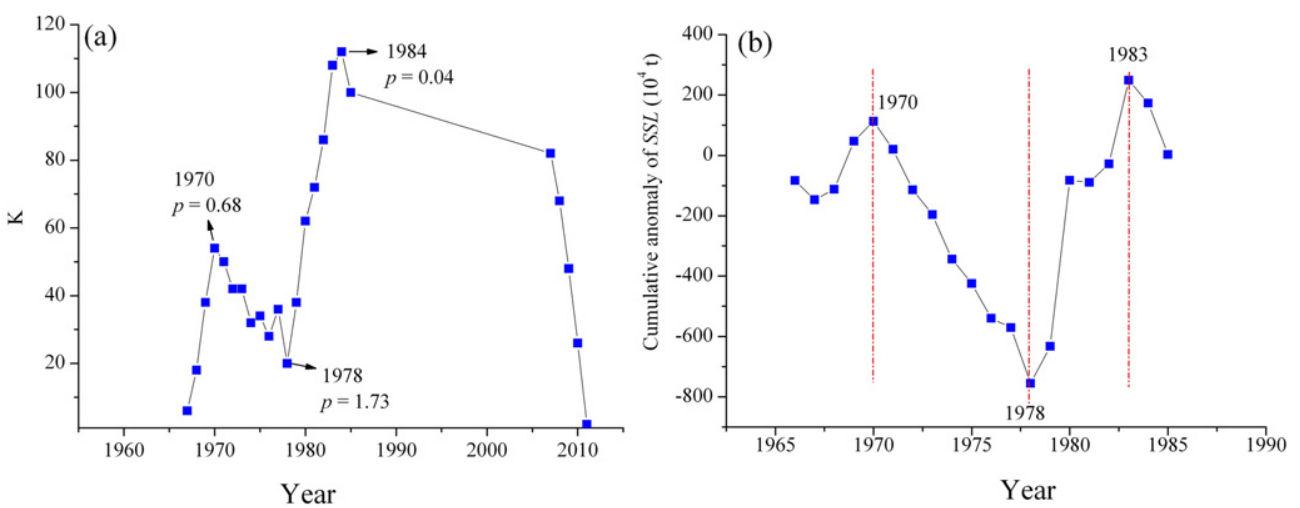

Fig. 3. Classification of suspended sediment load (a. Pettitt test result; b. Cumulative anomaly test result). 


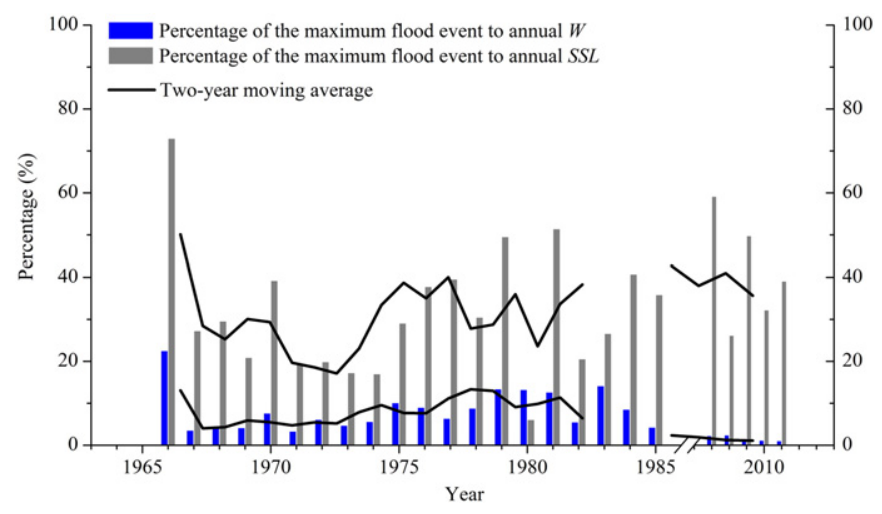

Fig. 5. Contributions of the maximum flood events to annual suspended sediment load and water yield.

Monthly SSC-Q hysteresis loops presented different patterns at four stages (Fig. 7). Monthly SSC-Q hysteresis loop showed figure-eight pattern in the years 1966-1970 (Fig. 7a). Counter-clockwise pattern was presented in monthly SSC-Q hysteresis loop during the years 1971-1978 and 2007-2011 (Fig. 7b and d). Clockwise hysteresis pattern occurred in the stage 1979-1985 (Fig. 7c). For all situations, the changing points of the monthly SSC-Q loops occurred in summer and early autumn (June to October), with the highest value at $0.83 \mathrm{~kg} / \mathrm{m}^{3}$ in June of 1985 (Fig. 7c).

Williams (1989) indicated that the SSC/Q ratio is an index in determining the pattern of SSC-Q hysteresis loops. SSC/Q in late winter and spring was higher than that in late autumn and early winter, resulted in the clockwise hysteresis loop in the years 1979-1985. The contrary situation resulted in the counter-clockwise pattern of monthly SSC-Q loop during the period 1971-1978 and 2007-2011. Although figureeight patterns (1966-1970) indicated more complicated situations, the $S S C / Q$ in late winter and spring was less than that in late autumn and early winter.

\subsection{Within-flood event variations of SSC}

Owing to their significant contributions to annual suspended sediment load, 34 maximum flood events were examined among the total 140 flood events (Table 2). $Q_{p}$ changed from 1050 to $6250 \mathrm{~m}^{3} / \mathrm{s}$ and the $S S C_{p}$ changed from 0.10 to $18.4 \mathrm{~kg} / \mathrm{m}^{3}$. 34 maximum flood events were classified into two types according to the occurring time of the $S S C_{P}$ and $Q_{p}$ (with the deviation of approximately $30 \mathrm{~min}$ ), Type I ( $S S C_{p}$ precedes $Q_{p}$ ) and Type II ( $S S C_{p}$ occurs at the same time as $Q_{p}$ ). The situation, that $S S C_{p}$ obviously lags the $Q_{p}$, indicated by Fang et al. (2008), did not occur in the maximum flood events during the studied period in the Loushui River. Among the total 34 maximum flood events,

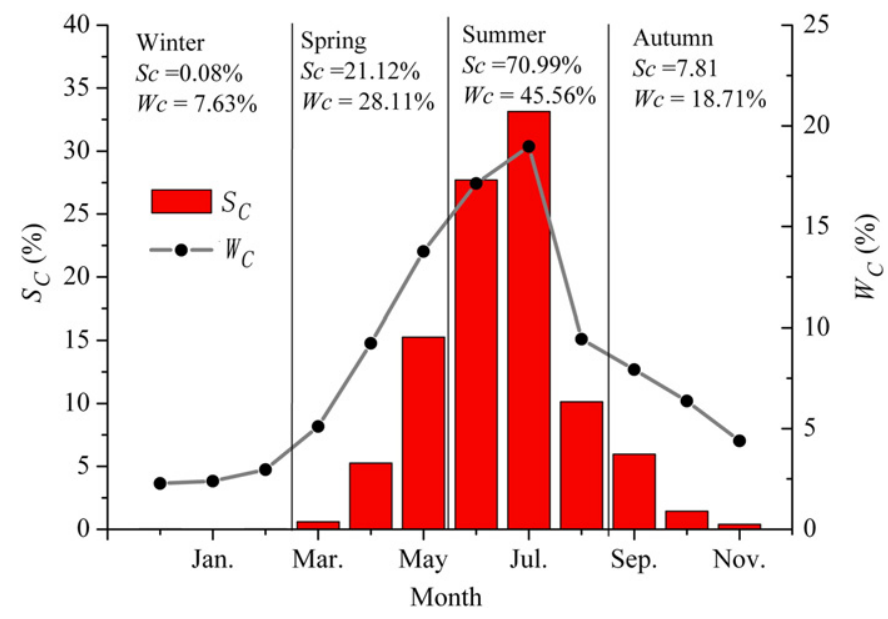

Fig. 6. Variations of monthly and seasonal suspended sediment load contribution (Sc) and water yield contribution (Wc) to annual value during the studied period.

Type I occupied 53\% and Type II occupied 47\%. During the period 1966-1970, most maximum flood events (83\%) belonged to Type I. During the period 1971-1978, Type I and Type II occurred with the same frequency. Next in the period 1979-1985, 56\% of the maximum flood events belonged to Type I. In the period 2007-2011, most maximum flood events (80\%) belonged to Type II. The mean $S S C_{p}$ for type I floods was $7.23 \mathrm{~kg} / \mathrm{m}^{3}$, $35 \%$ higher than the mean $S_{S C}$ of total 34 maximum flood events, while the mean $S S C_{p}$ for type II floods was $3.24 \mathrm{~kg} / \mathrm{m}^{3}$, 39\% less than the mean $S S C_{p}$ of total 34 maximum flood events. This implied that more suspended sediments were transported by Type I floods. The examples of different types of floods are shown in Fig. 8a, c (Type I) and Fig. 8e, g (Type II).

As shown in Table 2, the $M S S C_{p}$ and $M Q_{p}$ did not occur in the same flood event during the years 1969, 1971-1976, 1980 and 1983. Among these years, two situations existed, e.g. (i) $M S S C_{p}$ lags $M Q_{p}$ in $1969,1971,1974,1975$ and 1983 ; and (ii) $M S S C_{p}$ precedes $M Q_{p}$ in 1972 , 1973, 1976 and 1980.

SSC-Q hysteresis loops of the maximum flood events were presented in three patterns (Table 2), e.g. clockwise, counter-clockwise and figure-eight pattern, with the proportion at about $44 \%, 24 \%$ and $32 \%$, respectively. For Type I flood events, most SSC-Q loops followed clockwise behavior and seldom showed counter-clockwise behavior with the proportion at about $61 \%$ and $11 \%$, respectively. A different situation occurred for the Type II flood events, with more SSC-Q loops (about $44 \%$ ) showing figure-eight pattern. Clockwise and counter-clockwise hysteresis loops occupied $25 \%$ and $31 \%$, respectively.

Fig. 8 also shows the examples of different patterns of SSC $-Q$ loops (Fig. 8b, d, f, h). The hysteresis patterns were determined by the relations of $S S C / Q$ ratio in ring limbs of the $Q$-graph $\left((S S C / Q)_{r}\right)$ and the

Table 1

Relations of $W$, SSL, $P, Q$ and SSC during the studied period. ${ }^{a}$

\begin{tabular}{|c|c|c|c|}
\hline Years & $W-P$ & $S S L-P$ & $S S C-Q$ \\
\hline 1966-1970 & $\begin{array}{l}W=0.061^{* *} P-40.34 \\
R^{2}=0.928\end{array}$ & $\begin{array}{l}S S L=-0.004 P^{2}+13.11 P-9664.8 \\
R^{2}=0.717\end{array}$ & No significant correlations \\
\hline 1971-1978 & $\begin{array}{l}W=0.048^{* * *} P-20.24 \\
R^{2}=0.944\end{array}$ & $\begin{array}{l}S S L=-0.0004 P^{2}+1.30 P-949.2 \\
R^{2}=0.713\end{array}$ & $\begin{array}{l}S S C=0.015 Q^{0.553 x^{*}} \\
R^{2}=0.568\end{array}$ \\
\hline 1979-1985 & $\begin{array}{l}W=0.050^{* * *} P-25.98 \\
R^{2}=0.966\end{array}$ & $\begin{array}{l}S S L=0.001 P^{2}-3.31 P+2607.3 \\
R^{2}=0.866\end{array}$ & $\begin{array}{l}S S C=0.018 Q^{0.687 * *} \\
R^{2}=0.823\end{array}$ \\
\hline 2007-2011 & $\begin{array}{l}W=0.018^{*} P+20.46 \\
R^{2}=0.788\end{array}$ & $\begin{array}{l}S S L=0.0003 P^{2}-0.76 P+542.3 \\
R^{2}=0.711\end{array}$ & No significant correlations \\
\hline
\end{tabular}

Notes:

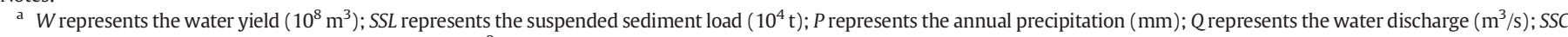
represents the suspended sediment concentration $\left(\mathrm{kg} / \mathrm{m}^{3}\right)$.

* significance level at $\mathrm{p}<0.05$.

** significance level at $\mathrm{p}<0.01$.

*** significance level at $\mathrm{p}<0.005$. 


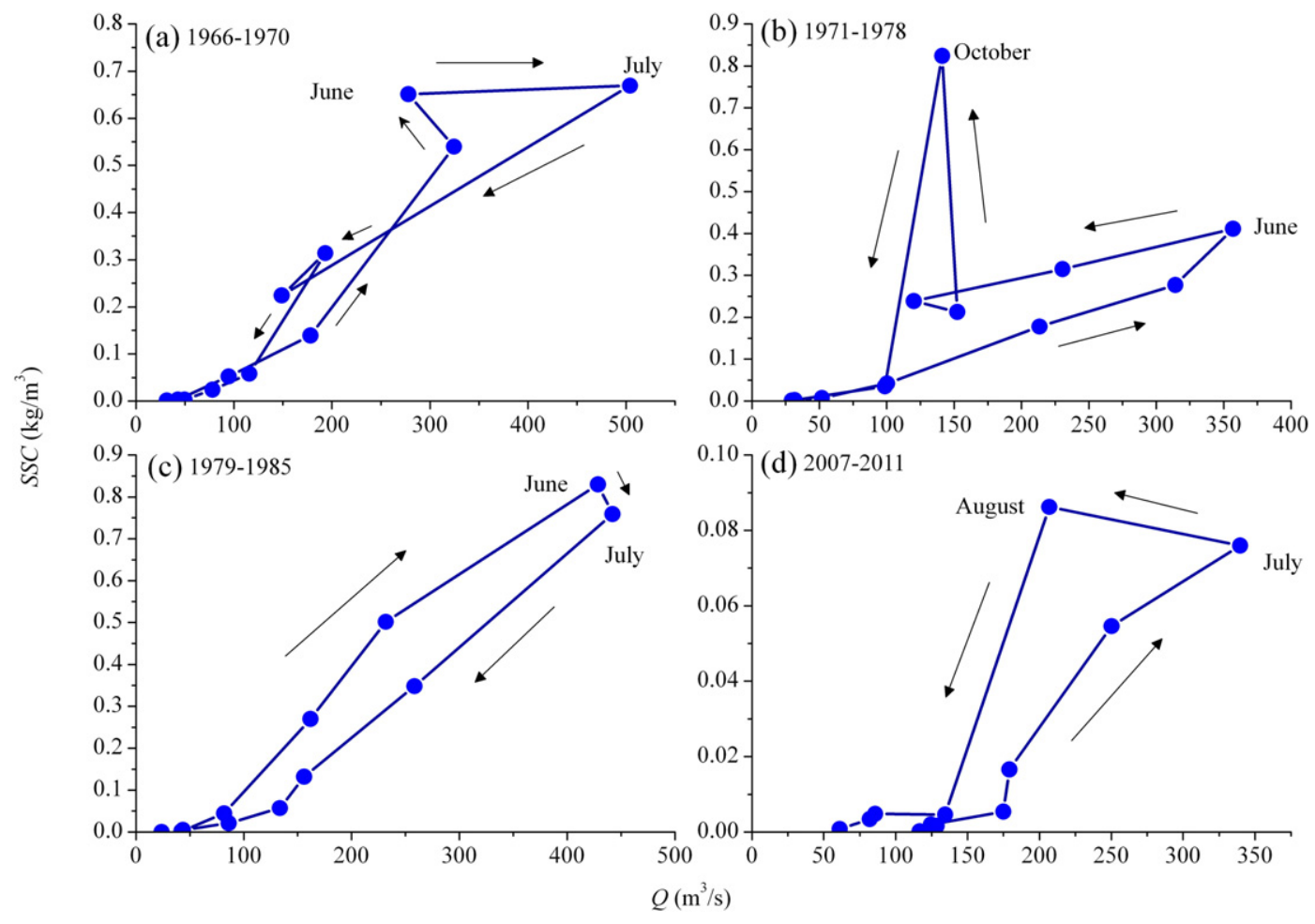

Fig. 7. Monthly SSC-Q hysteresis loops at four stages of the studied period.

SSC/Q in falling limbs of the $Q$-graph $\left((S S C / Q)_{f}\right)$ at the same $Q$ value (Paustian and Beschta, 1979; Williams, 1989). $(S S C / Q)_{r}>(S S C / Q)_{f}$ led to the clockwise loop (Fig. 8b). $(S S C / Q)_{r}<(S S C / Q)_{f}$ led to the counterclockwise loop (Fig. $8 \mathrm{~h}$ ). The variations of $(S S C / Q)_{r}$ and $(S S C / Q)_{f}$ relations in different $Q$ ranges induced the figure-eight pattern of SSC$Q$ loops. For example, $(S S C / Q)_{r}>(S S C / Q)_{f}$ when $Q<1700 \mathrm{~m}^{3} / \mathrm{s}$ and $(S S C / Q)_{r}<(S S C / Q)_{f}$ when $Q>1700 \mathrm{~m}^{3} / \mathrm{s}$ resulted in the figure-eight pattern in Type I flood event at 30-02/04-05/1973 (Fig. 8d). (SSC/Q) $r<(S S C / Q)_{f}$ when $Q<1700 \mathrm{~m}^{3} / \mathrm{s}$ and $(S S C / Q)_{r}>(S S C / Q)_{f}$ when $Q>1700 \mathrm{~m}^{3} / \mathrm{s}$ resulted in the figure-eight pattern with clockwise trend in Type II flood event at 14-17/07/1976 (Fig. 8f). All these results were well consistent with the theory by Williams (1989).

\section{Discussion}

\subsection{Influencing factors on annual variations of SSL}

SSL slowly decreased in period 1970-1978, re-increased in 1979-1985 and then sharply decreased in years 2007-2011 with the nearly constant $Q\left(450-540 \times 10^{7} \mathrm{~m}^{3}\right)$. Although no general consensus on the governing factors of suspended sediment dynamics exists, rainfall intensity, rainfall amount and land use changes are recognized as significant factors (Rodríguez-Blanco et al., 2010b; Schillint et al., 2011). In this work, the annual $W$ and $P$ showed significant positive correlations at four stages $\left(R^{2}>0.78\right)$ and did not change greatly at four stages (Table 1). Chen et al. (2014) also indicated that the precipitation may explain $80 \%$ of the discharge variance in Yangtze River. SSL had no good linear relationship with $P$, but presented a parabolic relationship (Table 1), because the sediment yield at the basin outlet is dominated by both soil erosion and sediment delivery processes, involving sediment delivery ratio and scale effects (Dai and Lu, 2014). In addition, the suspended sediment transport of the Loushui River was more easily being influenced by the seasonal precipitation than the annual precipitation, due to the significant contribution of flood events (Fig. 4), and this should be further investigated.
In addition, human activities may also have effects on the changing SSL. For instance, SSL may be increased by mining, forest cutting, poor farming practices and road construction, and decreased by water diversion, dam construction and soil conservation practices (Walling, 2006). Compared with years 1966-1970, the decrease of mean SSL in years 1970-1978 may be relevant with the small-scale reforestation and the working of the small-scale reservoirs. The re-increase of SSL in years 1978-1985 may be related to serious soil erosion. The continuing deforestation and cultivation on slope hills in 1950s-1970s resulted in serious soil erosion. For instance, in Cili County at the lower Loushui River, $26 \%$ of the area is suffering soil erosion in 1982. According to the survey data, the average erosion modulus was $2273-3695 \mathrm{t} / \mathrm{km}^{2}$ per year with the maximum modulus of $6089 \mathrm{t} / \mathrm{km}^{2}$ per year. The damages of smallscale reservoirs by the sedimentation also increase the SSL in this period. In the early 1980s, 29 small-scaled reservoirs were lost water storage capacity among 108 reservoirs in Cili County. Basically, the large-scale reforestation, like the Shelter Forest Ecology Project (started in 1990) and the National Program to Reconvert Farmland to Forests (started in 2000), could promote the sharp decrease of SSL after 2007. However, no great changes on land covers have been observed between 1986 and 2000 (Table 3), except the drastic increase of reservoir area (nearly 500 percentage). Batalla et al. (2004) have indicated that the reservoir has induced the reduction of flood magnitude in the Ebro River basin (NE Spain). In this work, the Jiangya reservoir was constructed in the middle Loushui River (during the years 1994-1999), with a distance of $48 \mathrm{~km}$ to the Changtanhe hydrometric station. By comparing the flood frequency, $S_{S C}$ and $M S S C_{p}$ before 1985 and after 2007 may help understand the impacts of the reservoir on SSL. The average flood frequency decreased from 6-7 times per year before 1985 to 2-3 times per year after 2007. Both the average $S S C_{p}$ and $M S S C_{p}$ decreased dramatically, from $2.6 \mathrm{~kg} / \mathrm{m}^{3}$ and $7.3 \mathrm{~kg} / \mathrm{m}^{3}$ before 1985 to $0.9 \mathrm{~kg} / \mathrm{m}^{3}$ and $1.3 \mathrm{~kg} / \mathrm{m}^{3}$ after 2007, respectively. These results implicated that both flood frequency and flood magnitude may be reduced by the construction of the Jiangya reservoir. On the contrary, no great changes were observed on the annual areal precipitation (averaged at 
Table 2

Maximum flood events during the studied period at Changtanhe hydrometric station.

\begin{tabular}{|c|c|c|c|c|c|c|c|}
\hline Date & $\begin{array}{l}Q_{p} \\
\text { Time }\end{array}$ & $Q_{p}\left(\mathrm{~m}^{3} / \mathrm{s}\right)$ & $\begin{array}{l}S S C_{p} \\
\text { Time }\end{array}$ & $\begin{array}{l}\mathrm{SSC}_{p} \\
\left(\mathrm{~kg} / \mathrm{m}^{3}\right)\end{array}$ & $\begin{array}{l}\text { Duration } \\
\text { (h) }\end{array}$ & Flood type & SSC $-Q$ hysteresis loop \\
\hline 27-02/06-07/1966 & $19: 00 / 29$ & $5510^{c}$ & $21: 36 / 28$ & $0.80^{\mathrm{d}}$ & 111 & $\mathrm{I}^{\mathrm{a}}$ & Clockwise \\
\hline $30-01 / 05-06 / 1967$ & $15: 30-16: 25 / 29$ & $4490^{c}$ & $12: 00 / 29$ & $4.69^{d}$ & 39 & I & Clockwise \\
\hline $18-19 / 07 / 1968$ & $7: 00 / 18$ & $4310^{c}$ & $6: 30 / 18$ & $8.55^{\mathrm{d}}$ & 32 & $\mathrm{II}^{\mathrm{a}}$ & Clockwise \\
\hline $04-06 / 07 / 1969^{b}$ & $16: 00 / 04$ & $5850^{c}$ & $14: 00 / 04$ & 5.34 & 46 & I & Clockwise \\
\hline $11-13 / 07 / 1969$ & $8: 18 / 12$ & 5750 & $6: 00 / 12$ & $6.29^{d}$ & 55 & I & Clockwise \\
\hline $28-30 / 05 / 1970$ & $23: 30 / 28$ & $3760^{c}$ & $13: 38 / 28$ & $12.70^{\mathrm{d}}$ & 66 & I & Clockwise \\
\hline $22-25 / 05 / 1971^{\mathrm{b}}$ & $9: 00-10: 00 / 23$ & $1540^{\mathrm{C}}$ & $9: 40 / 23$ & 3.02 & 61 & II & Clockwise \\
\hline $04-06 / 09 / 1971$ & $8: 00 / 05$ & 1050 & $8: 00 / 05$ & $4.32^{\mathrm{d}}$ & 48 & II & Figure-eight \\
\hline $27-29 / 05 / 1972^{\mathrm{b}}$ & $13: 30 / 28$ & 2450 & $3: 30 / 28$ & $1.95^{\mathrm{d}}$ & 40 & I & Clockwise \\
\hline $26-29 / 06 / 1972$ & $14: 00 / 26$ & $2520^{c}$ & $14: 36 / 26$ & 1.91 & 78 & II & Figure-eight \\
\hline $30-02 / 04-05 / 1973^{b}$ & $18: 00 / 30$ & 1990 & $13: 34 / 30$ & $3.93^{d}$ & 69 & $\mathrm{I}$ & Figure-eight \\
\hline $23-24 / 06 / 1973$ & $20: 00 / 23$ & $3510^{c}$ & $19: 38 / 23$ & 2.82 & 64 & II & Figure-eight \\
\hline $16-21 / 05 / 1974^{\mathrm{b}}$ & $15: 15 / 29$ & $2080^{c}$ & $15: 00 / 29$ & 2.39 & 116 & II & Counter-clockwise \\
\hline $29-01 / 09-10 / 1974$ & $19: 30 / 29$ & 1950 & $6: 36 / 29$ & $9.44^{\mathrm{d}}$ & 75 & I & Clockwise \\
\hline $09-13 / 06 / 1975^{\mathrm{b}}$ & $5: 30 / 10$ & $3900^{c}$ & $6: 00 / 10$ & 2.36 & 102 & II & Clockwise \\
\hline $09-10 / 08 / 1975$ & $23: 00 / 09$ & 1120 & $10: 30 / 09$ & $11.30^{\mathrm{d}}$ & 28 & I & Clockwise \\
\hline $22-25 / 06 / 1976^{\mathrm{b}}$ & $22: 00 / 22$ & 2460 & $17: 00 / 22$ & $5.11^{\mathrm{d}}$ & 63 & I & Counter-clockwise \\
\hline $14-17 / 07 / 1976$ & $18: 00 / 14$ & $4010^{c}$ & $17: 46 / 14$ & 3.21 & 72 & II & Figure-eight \\
\hline $17-20 / 07 / 1977$ & $4: 00 / 19$ & $2770^{c}$ & $23: 58 / 18$ & $6.64^{d}$ & 71 & I & Counter-clockwise \\
\hline $30-01 / 05-06 / 1978$ & $20: 06 / 30$ & $2670^{c}$ & $18: 16 / 30$ & $6.64^{\mathrm{d}}$ & 60 & I & Figure-eight \\
\hline $04-07 / 06 / 1979$ & $20: 00 / 04$ & $5520^{c}$ & $10: 18 / 04$ & $14.6^{\mathrm{d}}$ & 62 & I & Clockwise \\
\hline $31-02 / 05-06 / 1980^{\mathrm{b}}$ & $18: 00 / 31$ & 3960 & $7: 30 / 31$ & $18.4^{\mathrm{d}}$ & 63 & I & Figure-eight \\
\hline 30-04/07-08/1980 & $12: 00-14: 00 / 02$ & $6250^{c}$ & $13: 00 / 02$ & 4.79 & 100 & II & Counter-clockwise \\
\hline $18-20 / 04 / 1981$ & $14: 00 / 18$ & $4290^{c}$ & $13: 00 / 18$ & $8.56^{\mathrm{d}}$ & 40 & I & Clockwise \\
\hline $11-14 / 07 / 1982$ & $23: 00 / 11$ & $2290^{c}$ & $23: 00 / 11$ & $4.64^{\mathrm{d}}$ & 70 & II & Counter-clockwise \\
\hline $24-01 / 06-07 / 1983^{b}$ & $22: 00 / 26$ & $5970^{c}$ & $16: 00 / 25$ & 4.04 & 170 & I & Figure-eight \\
\hline $05-10 / 07 / 1983$ & $13: 00 / 05$ & 5910 & $13: 28 / 05$ & $7.76^{\mathrm{d}}$ & 151 & II & Counter-clockwise \\
\hline $14-17 / 06 / 1984$ & $0: 00 / 15$ & $2800^{c}$ & $20: 00 / 14$ & $6.64^{d}$ & 86 & I & Figure-eight \\
\hline $05-06 / 05 / 1985$ & $19: 25 / 05$ & $2620^{c}$ & $19: 00 / 25$ & $2.75^{\mathrm{d}}$ & 33 & II & Clockwise \\
\hline $22-26 / 07 / 2007$ & $16: 54 / 23$ & $3560^{c}$ & $17: 18 / 23$ & $1.24^{\mathrm{d}}$ & 95 & II & Figure-eight \\
\hline $15-18 / 08 / 2008$ & $7: 50 / 16$ & $2080^{c}$ & $14: 10 / 15$ & $3.09^{d}$ & 72 & I & Clockwise \\
\hline $08-09 / 06 / 2009$ & $19: 00 / 08$ & $3020^{c}$ & $19: 25 / 08$ & $1.52^{\mathrm{d}}$ & 23 & II & Counter-clockwise \\
\hline $11-13 / 07 / 2010$ & $14: 00 / 11$ & $2690^{c}$ & $14: 00 / 11$ & $0.10^{\mathrm{d}}$ & 69 & II & Counter-clockwise \\
\hline $18-19 / 06 / 2011$ & $12: 15 / 18$ & $2370^{c}$ & $12: 25 / 18$ & $0.38^{\mathrm{d}}$ & 31 & II & Figure-eight \\
\hline
\end{tabular}

Notes:

a Type I, the peak suspended sediment concentration $\left(S S C_{p}\right)$ precedes the peak water discharge $\left(Q_{p}\right)$; Type II SSC $C_{p}$ occurs at the same time as $Q_{p}$.

b In which year, the maximum peak water discharge $\left(M Q_{p}\right)$ and the maximum peak suspended sediment concentration $\left(\right.$ MSSC $\left._{p}\right)$ do not occur in the same flood event.

c Is the $M Q_{p}$ value.

d Is the MSSC $C_{p}$ value.

$1560 \mathrm{~mm}$ before 1985; at $1577 \mathrm{~mm}$ after 2007) and the average $Q_{p}$ of flood events (averaged at $2240 \mathrm{~m}^{3} / \mathrm{s}$ before 1985; at $2063 \mathrm{~m}^{3} / \mathrm{s}$ after 2007) at Changtanhe station. Considering the great contributions of the maximum flood events to SSL (averaged at 41\%, Fig. 5) after 2007, the dramatically decreased MSSC $_{p}$ of flood events after the construction of the Jiangya reservoir may lead to the sharp decrease of SSL after 2007. Due to lacking data before 1985 and after 2007, the influences of reforestation and other land use changes should be investigated.

\subsection{Seasonal sediment 'store-release'}

The seasonal 'store-release' process was used to explain the changing monthly SSC-Q loops in watersheds of Loess Plateau area, China (Xu, 2000; Fang et al., 2008). Fang et al. (2008) indicated that sediment is prepared in the basin by weathering, human activities and the erosion process during the store phase (winter, spring and later autumn), while most of the sediment is transported downstream in the following release phase (summer and early autumn). In this study, the similar 'store-release' process was also observed in the Loushui River, subtropical area of south-central China. The highest SSC occurred in the summer and early autumn, implicated the material released rapidly by the high frequency of flood events. However, SSC is much lower during the store phase in winter, spring and late autumn and sediment is prepared in channel bank or channel bed as suspended sediment source materials by complicated processes, involving soil and climatic condition, runoff and tillage. In the Loushui River basin, soils are developed in the weathering crust of the sedimentary rocks. Large amounts of sediment sources were caused by regolith weathering and its related landslide (Yang et al., 2011b). Especially in areas at the lower Loushui River (where Changtanhe station is located), the interaction of freezingthawing process, weathering and strong wind may cause landslide at middle and lower parts of sandstones in winter and early spring. As a result of three cropping system (Liu et al., 2014), severe soil erosion caused by the cultivation on slopes also provides sediment source materials in spring and late autumn. Due to the low water discharge in the storage phase (Fig. 6), parts of the sediment source materials were not taken away and remained in water course. Considering the seasonal Sc, Wc (Fig. 6) and the monthly SSC-Q loops (Fig. 7), it was deduced that more sediments were stored in winter and spring during the period 1966-1978 and 2007-2011, with lower SSC/Q in winter and spring than in late autumn. However, more materials were stored in late autumn during the period 1979-1985 with higher SSC/Q in winter and spring.

\subsection{Sediment availability changes}

The patterns of SSC-Q loops for the maximum flood events were especially discussed, due to its average contribution to the total annual SSL at approximately 32\% before 1985 and at 41\% after 2007 (Fig. 5). The SSC-Q hysteresis patterns could be used to deduce the sediment availability. For clockwise loop, usually there is a fast increase of SSC at the beginning of the flood event, meaning the enough available sediment in the water course (Lenzi and Lorenzo, 2000; Gentile et al., 2010). 

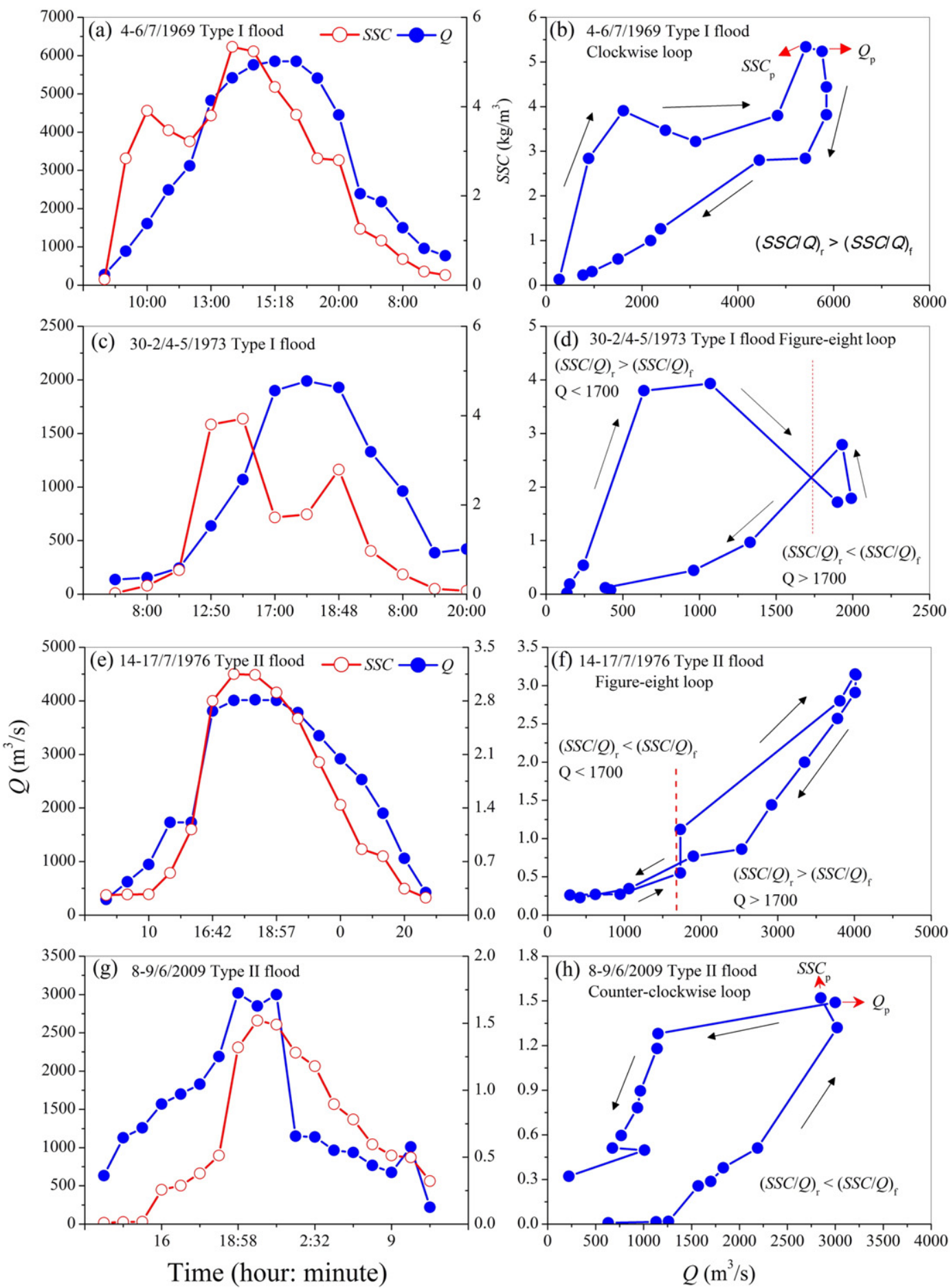

Fig. 8. Examples of different types of maximum flood events and their SSC-Q hysteresis loops at four stages.

Table 3

Land use changes in the Loushui River basin.

\begin{tabular}{lrrc}
\hline \multirow{2}{*}{ Land use type } & \multicolumn{2}{c}{ Area percentage (\%) } & Variation (\%) \\
\cline { 2 - 3 } & 1986 & 2000 & \\
\hline Grassland & 6.80 & 6.90 & +1.47 \\
Shrub & 14.30 & 12.20 & -14.68 \\
Forest & 66.68 & 66.97 & +0.44 \\
Reservoir & 0.02 & 0.13 & +550 \\
Dry land & 4.20 & 4.10 & -2.38 \\
Paddy field & 3.40 & 3.30 & -2.94 \\
Others & 4.60 & 6.40 & +39.13 \\
\hline
\end{tabular}

This kind of material is usually near the catchment outlet or in the channel bed (Smith and Dragovich, 2009; López-Tarazón et al., 2009). For counter-clockwise loops, increasing SSC on the falling limb during floods may suggest relatively more available sediment with lower aggregate stability, usually contributed by surface runoff or far end of the area (Brasington and Richards, 2000; Orwin and Smart, 2004). This part of sediment is usually the particles eroded within the catchment, settling on the slope before being transported by the next flood event (Oeurng et al., 2010). Mixed pattern, like figure-eight, means more complicated situations that were poorly investigated in the literature (e.g. Gentile et al., 2010). 
The changes of SSC-Q hysteresis patterns of the maximum flood events with time (Table 2) implied the variations of suspended sediment availability in different stages of the studied period. During the period 1966-1970, all maximum flood events belonged to Type I with clockwise loops. This indicated sediment available in water course or channel bed (SSC ranged from 0.8 to $12.7 \mathrm{~kg} / \mathrm{m}^{3}$, averaged at $6.4 \mathrm{~kg} / \mathrm{m}^{3}$, Table 2). Because of the sufficient sediment sources, $S S C_{p}$ precedes $Q_{p}$ in the maximum flood event. During the period 1971-1978, the maximum floods were fallen into Type I and Type II with nearly the same frequency (Table 2). Clockwise and figure-eight hysteresis patterns were majority (79\%), with an average $S C_{p}$ at $4.6 \mathrm{~kg} / \mathrm{m}^{3}$ (from 1.9 to $11.3 \mathrm{~kg} / \mathrm{m}^{3}$, Table 2). It was deduced that sediment source materials supplied in the water course or channel bed were not as sufficient as during the period 1966-1970. Parts of the suspended sediment were sourced from the hills or upper reaches. Because the materials stored in water course or channel bed were not enough, the average $S_{S C}$ was a bit lower than before. During the period 1979-1985, Type I and Type II floods also occurred with nearly the same frequency. Counter-clockwise and figure-eight patterns occupied $60 \%$, with an average $S S C_{p}$ at $8.0 \mathrm{~kg} / \mathrm{m}^{3}$ (from 2.8 to $18.4 \mathrm{~kg} / \mathrm{m}^{3}$, Table 2). In this stage, it was assumed that more suspended sediments transported by the maximum flood event were from materials stored on hills or upper reaches and less sediment from the water course, due to the available sediment depletion in water channel/bed near the outlet. During the period 2007-2011, most maximum floods belonged to Type II. Counter-clockwise and figure-eight were dominant (occupied $80 \%$ ), with an average $S S C_{p}$ at $1.3 \mathrm{~kg} / \mathrm{m}^{3}$ (from 0.1 to $3.1 \mathrm{~kg} / \mathrm{m}^{3}$, Table 2). Materials on hills or upper reaches may be the dominant sources transported by the maximum flood events in this stage. It was assumed that the reduction of soil erosion or other human activities, like the huge increase (nearly 500 percentage) in the area of reservoirs in middle reaches of the Loushui River (Table 3), may reduce the $S S C_{p}$ of the maximum flood events in this stage as discussed above.

\section{Conclusions}

The overall aim of this research was to investigate the variations of suspended sediment transport at different temporal scales in the Loushui River, one of the secondary tributaries of the Yangtze River passing through Zhangjiajie region in humid subtropical south-central China.

Annual SSL slowly decreased in period 1970-1978, re-increased in 1979-1985 and then sharply decreased in years 2007-2011 with the nearly constant $Q\left(450-540 \times 107 \mathrm{~m}^{3}\right)$. SSL showed more complicated relations (parabolic relationship) with annual precipitation, partially due to the significant contribution of flood events (averaged at $78 \%$ before 1985 and at 55\% after 2007). Despite no distinct changes in the annual precipitation and vegetation cover, there was still a sharp decrease of suspended sediment loading after 2007. This was caused by the decrease in flood frequency and sediment concentration of flood peaks induced by the construction of the Jiangya reservoir in the middle Loushui River.

The monthly SSL ranged from $0.01 \times 10^{4}$ to $59.77 \times 10^{4}$ t, contributing to $33 \%$ of the annual SSL in July. Seasonally, approximately $71 \%$ of the total suspended sediment was transported during the summer. The various patterns of SSC-Q hysteresis loops indicated the changing storage seasons at four stages of the studied period, which could be explained by the seasonal 'store-release' process. Materials were mainly stored in late autumn during the period 1979-1985, while more materials were stored in winter and spring during the period 1966-1978 and 2007-2011.

Moreover, the variations of dominant SSC-Q hysteresis loops for the maximum flood events at different stages of the studied period, implicated the changing suspended sediment sources from water courses near the outlet to hills or upper reaches with time. To some extent, the variations of sediment availability are controlled by soil erosion rate on slopes in the Loushui River basin, and this should be further investigated. Moreover, due to the lack of land use data before 1985 and after 2007, the influences of reforestation and other human activities on the suspended sediment dynamics should be further considered.

\section{Acknowledgment}

The authors wish to acknowledge the Special Foundation for Protection of Geoheritages in Zhangjiajie World Geopark and National Natural Science Foundation of China (41471229; 41271304).

\section{References}

Andermann, C., Crave, A., Gloaguen, R., Davy, P., Bonnet, S., 2012. Connecting source and transport: Suspended sediments in the Nepal Himalayas. Earth Planet. Sci. Lett. 351-352, 158-170.

Batalla, R.J., Gomez, C.M., Kondolf, G.M., 2004. Reservoir-induced hydrological changes in the Ebro River basin (NE Spain). J. Hydrol. 290, 117-136.

Brasington, J., Richards, K., 2000. Turbidity and suspended sediment dynamics in small catchments in the Nepal Middle Hills. Hydrol. Process. 14, 2559-2574.

Brown, A.E., Zhang, L., McMahon, T.A., Western, A.W., Vertessy, R.A., 2005. A review of paired catchment studies for determining changes in water yield resulting from alterations in vegetation. J. Hydrol. 310, 28-61.

Chen, J., Wu, X.D., Finlayson, B.L., Webber, M., Wei, T.Y., Li, M.T., Chen, Z.Y., 2014. Variability and trend in the hydrology of the Yangtze River, China: Annual precipitation and runoff. J. Hydrol. 513, 403-412.

Dai, S.B., Lu, X.X., 2014. Sediment load change in the Yangtze River (Changjiang): A review. Geomorphology 215, 60-73.

Duvert, C., Gratiot, N., Evrard, O., Navratil, O., Némery, J., Prat, C., Esteves, M., 2010. Drivers of erosion and suspended sediment transport in three headwater catchments of the Mexican Central Highlands. Geomorphology 123, 243-256.

Fan, X.L., Shi, C.X., Zhou, Y.Y., Shao, W.W., 2012. Sediment rating curves in the NingxiaInner Mongolia reaches of the upper Yellow River and their implications. Quat. Int 282, 152-162.

Fang, H.Y., Cai, Q.G., Chen, H., Li, Q.Y., 2008. Temporal changes in suspended sediment transport in a gullied loess basin: the lower Chabagou Creek on the Loess Plateau in China. Earth Surf. Proc. Land. 33, 1977-1992.

Fang, N.F., Shi, Z.H., Li, L., Jiang, C., 2011. Rainfall, runoff, and suspended sediment delivery relationships in a small agricultural watershed of the Three Gorges area, China. Geomorphology 135, 158-166.

Ferguson, R.I., 1986. River loads underestimated by rating curves. Water Resour. Res. 22 74-76.

Gao, P., Pasternack, G., 2007. Dynamics of suspended sediment transport at field-scale drain channels of irrigation-dominated watersheds in the Sonoran Desert, southeastern California. Hydrol. Process. 21, 2081-2092.

Gentile, F., Bisantino, T., Corbino, R., Milillo, F., Romano, G., Liuzzi, G.T., 2010. Monitoring and analysis of suspended sediment transport dynamics in the Carapelle torrent (Southern Italy). Catena 80, 1-8.

Jansson, M.B., 2002. Determining sediment source areas in a tropical basin, Costa Rica. Catena 47, 63-84.

Lenzi, M.A., Marchi, L., 2000. Suspended sediment load during floods in a small stream of the Dolomites (northeastern Italy). Catena 39, 267-282.

Liu, S.L., Huang, D.Y., Chen, A.L., Wei, W.X., Brookes, P.C., Li, Y., Wu, J.S., 2014. Differential responses of crop yields and soil organic carbon stock to fertilization and rice straw incorporation in three cropping systems in the subtropics. Agric. Ecosyst. Environ. 184, 51-58.

López-Tarazón, J.A., Batalla, R.J., Vericat, D., Francke, T., 2009. Suspended sediment transport in a highly erodible catchment: The River Isábena (Southern Pyrenees). Geomorphology 109, 210-221.

López-Tarazón, J.A., Batalla, R.J., Vericat, D., Balasch, J.C., 2010. Rainfall, runoff and sediment transport relations in a mesoscale mountainous catchment: The River Isábena (Ebro basin). Catena 82, 23-34

Miao, C.Y., Ni, J.R., Borthwick, A.G.L., Yang, L., 2011. A preliminary estimate of human and natural contributions to the changes in water discharge and sediment load in the Yellow River. Global Planet. Change 76, 196-205.

Nistor, C.J., Church, M., 2005. Suspended sediment transport regime in a debris-flow gully on Vancouver Island, British Columbia. Hydrol. Process. 19, 861-885.

Oeurng, C., Sauvage, S., Sánchez-Pérez, J.-M., 2010. Dynamics of suspended sediment transport and yield in a large agricultural catchment, southwest France. Earth Surf. Proc. Land. 35, 1289-1301.

Orwin, J.F., Smart, C.C., 2004. The evidence for paraglacial sedimentation and its tempora scale in the deglacierizing basin of Small River Glacier, Canada. Geomorphology 58 $175-202$.

Paustian, S.J., Beschta, R.L., 1979. The suspended sediment regime of an Oregon Coast Range stream. Water Res. Bull. 15, 144-154.

Pettitt, A.N., 1979. A non-parametric approach to the change-point problem. Appl. Statist 28, 126-135.

Picouet, C., Hingray, B., Olivry, J.C., 2001. Empirical and conceptual modeling of the suspended sediment dynamics in a large tropical African river: the upper Niger River basin. J. Hydrol. 250, 19-39. 
Ran, L.S., Wang, S.J., Fan, X.L., 2010. Channel change at Toudaoguai Station and its responses to the operation of upstream reservoirs in the upper Yellow River. J. Geogr. Sci. 20 (2), 231-247.

Richards, G., Moore, R.D., 2003. Suspended sediment dynamics in a steep, glacier-fed mountain stream, Place Creek, Canada. Hydrol. Process. 17, 1733-1753.

Rodríguez-Blanco, M.L., Taboada-Castro, M.M., Palleiro, L., Taboada-Castro, M.T., 2010a. Temporal changes in suspended sediment transport in an Atlantic catchment, NW Spain. Geomorphology 123, 181-188.

Rodríguez-Blanco, M.L., Taboada-Castro, M.M., Taboada-Castro, M.T., 2010b. Factors controlling hydro-sedimentary response during runoff events in a rural catchment in the humid Spanish zone. Catena 82, 206-217.

Rovira, A., Batalla, R.J., 2006. Temporal distribution of suspended sediment transport in Mediterranean basin: The Lower Tordera (NE SPAIN). Geomorphology 79, 58-71.

Schillint, K.E., Isenharg, T.M., Palmer, J.A., Wolter, C.F., Spooner, J., 2011. Impacts of landcover change on suspended sediment transport in two agricultural watersheds. J. Am. Water Resour. Assoc. 47, 672-686.

Smith, H.G., Dragovich, D., 2009. Interpreting sediment delivery processes using suspended sediment-discharge hysteresis patterns from nested upland catchments, south-eastern Australia. Hydrol. Process. 23, 2415-2426.

Walling, D.E., 2006. Human impact on land-ocean sediment transfer by the world's rivers. Geomorphology 79, 192-216.

Walling, D.E., Fang, D., 2003. Recent trends in the suspended sediment loads of the world's rivers. Global Planet. Change 39, 111-126.
Wang, S.J., Yan, M., Yan, Y.X., Shi, C.X., He, L., 2012a. Contributions of climate change and human activities to the changes in runoff increment in different sections of the Yellow River. Quat. Int. 282, 66-77.

Wang, S.J., Yan, Y.X., Yan, M., Zhao, X.K., 2012b. Quantitative estimation of the impact of precipitation and human activities on runoff change of the Huangfuchuan River Basin. J. Geogr. Sci. 22 (5), 906-918.

Williams, G.P., 1989. Sediment concentration versus water discharge during single hydrologic events in rivers. J. Hydrol. 111, 89-106.

Xu, J.X., 2000. Grain-size characteristics of suspended sediment in the Yellow River, China. Catena 38, 243-263.

Yang, G.F., Yang, Z., Zhang, X.J., Tian, M.Z., Chen, A.Z., Ge, Z.L., Ping, Y.M., Ni, Z.Y., 2011a. RSbased geomorphic analysis of Zhangjiajie Sandstone Peak Forest Geopark, China. J. Cult. Herit. 12, 88-97.

Yang, G.F., Zhang, X.J., Tian, M.Z., Brierley, G., Chen, A., Ping, Y.M., Ge, Z.L., Ni, Z.Y., Yang, Z., 2011b. Alluvial terrace systems in Zhangjiajie of northwest Hunan, China: Implications for climatic change, tectonic uplift and geomorphic evolution. Quat. Int. 233, 27-39.

Yang, G.F., Tian, M.Z., Zhang, X.J., Chen, Z.H., Wray, R.A.L., Zhiliang, G., Yamin, P., Zhi, Y.N., Zheng, Y., 2012. Quartz sandstone peak forest landforms of Zhangjiajie Geopark, northwest Hunan Province, China: pattern, constraints and comparison. Environ. Earth Sci. 65, 1877-1894. 